\title{
Political Culture and Democratic Transition in West Africa: The Nigerian Experience
}

\author{
Ibrahim Baba \\ Department of Public Administration, Mai Idris Alooma Polytechnic, P. M. B. 1020, Geidam, Yobe State, Nigeria
}

Copyright $(2015$ Horizon Research Publishing All rights reserved.

\begin{abstract}
The transfer of political power from one civilian regime to another in West Africa have often been accompanied by violence promoted by desires of parties in power to consolidate their grips on power and by opposition parties interest to capture same by hook or crook in some other cases. The attitudes of the electorates of making themselves available to the politicians to be use in promoting elections and post-election violence itself is not helping the development of democracy and party politics in the west Africa. Conducted with the use of quantitative research methodology, this essay examines the relationship between political culture and democratic transition in West Africa. It examines the political behaviors and attitudes of people in the region towards transfer of political power from one to another civilian regime. Experiences gathered from such development in Nigeria were also examined in the study. The work also examines the need for attitudinal and paradigm shift in relations to democratic transition in West Africa and Nigeria in particular. What causes election and post-election violence, how are these violence sponsored and why should these conflicts be avoided are some of the major questions examined in this work. The work is also written with ideas drawn from the works of great comparative and behaviorists Political Scholars like Gabriel Almond, David Easton, Maurice Durverger, Graham Wallace, Author Bentley et al.
\end{abstract}

Keywords Political, Culture, Democratic, Transition, Experience, Elections, Post-election

\section{Introduction}

In countries situated west of Africa, democratic development and party politics are often undermined by political behaviors of people garnished by political party interests to consolidate their grips on control of state power for life. Party politics in this region of the continent itself is operated based on zero sum game theory basis-situation that contributes to the tense nature of struggle to capture and retain political power in the region. Civilianization of regimes in this region of the continent were not accompanied by conflicts and violence promoted by political culture. People in West Africa were already tired with dictatorship and undemocratic government when democratization was finding ground in the region in the mid and late 1990s. The need then was for soldiers to return to their constitutional role of protecting the territorial integrity of state and to quit political power without any contemplation. Therefore, this transfer of political power was not in many ways accompanied with violence and after elections violence. In some countries like Ghana and Nigeria, total transfer of power from soldiers to civilians were witnessed while in places like Gambia and Mauritania civilianization took place-military heads of state transformed into civilian heads of government. Conflicts situations are often witnessed in cases where an incumbent civilian regime is expected to transfer political power to another elected civilian head of government.

Successful democratic transition is a recent development in West Africa. In countries where soldiers civilianized into white cloth leaders, they stay put and never want to leave again until they are removed forcefully through rebellion. Both Master Sergeants Samuel Doe in Liberia and Thomas Sankara in Boukina Faso succeeded themselves as civilian heads of state from the military juntas they once headed before they were murdered in cool blooded manner-a development that cost them not only their lives but also the age-long regimes they headed. In the tiny West African state of Gambia, Yahaya Jameh also succeeded himself by civilianizing into a plain cloth head of government. Till date he has consecutively influence the parliament to amend the country constitution especially $\mathrm{n}$ related to tenure limits which has been making it possible for him to contest, manipulate and consolidate his grip on state power. This development has often triggered political tension in the country and condemnations from outside the Gambia. Transfer of political power from one civilian head of government to another is as earlier stated a recent experience in the political culture of the West African people. Some countries in this region of the continent are not familiar with this sort of change of government. And this could probably 
be one of the reasons why this kind of transfer of political power is often accompanied with conflicts and contradictions in this region of the continent.

Ghana considered as the most democratically stable country in West Africa also experienced a partial sort of post-election violence incubated by democratic transition that led to the re-election of John Drahman Mahaman after the death of John Atta Mills. The beliefs that ruling parties always want to retain political power for long and opposition parties want to capture same at the end of every elective tenure are very sound in the political culture of the people of West Africa. The attitudes of celebrating ruling parties lost and opposition victory in elections at the expiration of every elective tenure are also common in the attitudes of the West African people. The common attitudes of demonstrating and carrying out crises when election results are announced in favor of ruling party are also common in the attitudes of most people in this region of the continent. Presidential elections conducted to ensure democratic transition of political power announced in favor of the ruling People's Democratic Party (PDP) believed to have been rigged by the ruling party resulted into post-election violence that culminated the massacre of over two hundred innocent citizen across the north-western states of Kaduna and Kano. The attitude of not accepting defeat in good faith is also part of the political culture of the people of West Africa. Politicians have been accused of selfishly igniting post-election conflicts to drive home their demand in the region. The controversial post-election violence that graduated into full fledge civil war after Gbagbo upturned results earlier announced to have been won by AL-Hassan Quottara is still fresh on the minds of the Ivorian people. The ghosts of innocent citizens killed in related and similar development across Sierra Leon till date have refused to returned to their final resting places and abodes.

Political culture of the people of West Africa embodies mix behaviors from both the citizens and political elites themselves. Electorates or ordinary citizens are the tools for perpetuating political violence while some of these conflicts are born out of politicians impatient and unethical attitudes. Political misbehaviors exhibited by politicians in some cases have often been used by the military as an excuse to overthrow elected government-situation that has affected democratic development in most cases. Tanja 's intention to manipulate Niger's presidential tenure limit provided by law of the country resulted into military takeover of government and suspension of democratic processes in the country. These unethical political behaviors of politicians also contributed in the low paste of democratic development recorded in the West African state of Nigeria where most of the vital years of the nation shortly after political independence were wasted under military rule.

\section{Political Culture}

The nature of society determines its political culture and system of organization in relations to government and political system. Society can be homogeneous and some other ones can also be heterogeneous in nature. Homogeneous society is one in which similarity in culture and general way of life overshadowed differences while the heterogeneous society is one in which differences in way of life outnumbered similarities. The heterogeneous and homogeneous nature of society affect the behaviors of citizens in relations to politics. Political behaviors of citizens in homogeneous society are greatly similar than of citizens in heterogeneous society. This is partly because of the uniformity and similarity in culture and beliefs in the case of homogeneous setup and disparity in same as in the case of heterogeneous set up. In both homogeneous and heterogeneous societies, Lijphart as Almond et al (2006) wrote submits that political culture can be mass and elite in nature. Mass political culture is use to defined the behaviors of the masses in relations to politics while elite political culture is use to explain the ruling class behaviors to politics. Nigeria is a heterogeneous society therefore, similar political behavior on the part of its citizen is never a possible development. Polazzo (2014) asserts that Nigeria is one of the most fragmented countries in the world. Its division as Lewis (1994) observed is largely along overlapping religious and ethnic lines.

Almond and Verba (1965) posits that political culture is a set of attitudes, beliefs and sentiments that give order and meaning to a political process and which provide the underlying assumptions and rules that govern behavior in the political system. Ketzner (1988) confirms that it encompasses both the political ideals and operating norms of a polity. In developing countries, Diamond (1984) conceives that political culture is thus the manifestation in aggregate form of the psychological and subjective dimensions of politics. While in Almond et al (2006) political culture is described as the product of both the collective history of a political system and the life histories of the members of the system and thus it is rooted equally in public events and private experience. Political culture as rightly stated above deals with citizens' attitudes and behaviors in reactions to political events and development. Elazar (1972) confirms that it refers to what people believe and feel about government, and how they think people should act towards it. Feelings and thinking's are part of behavior. The way people feel determines what they think and what people think determine what they do and what they do is their behaviors. In fact Roskin (2014) states that political culture is the political psychology of a country or nation.

Political culture is a set of attitudes and practices held by a people that shapes their behavior. It includes moral judgments, political myths, beliefs, and ideas about what makes for a good society. A political culture is a reflection of a government, but it also incorporates elements of history and tradition that may predate the current change regime. Political cultures matter because they shape a population's political perceptions and actions. Governments can help shape political culture and public opinion through education, 
public events, and commemoration of the past. Political cultures vary greatly from state to state and sometimes even within a state. Generally speaking, however, political culture remains more or less the same over time. Political culture is connected to notions of citizenship because political culture frequently includes an idea of what makes people good citizens. Political culture studies attempt to uncover deep-seated, long-held values characteristic of a society or group rather than ephemeral attitudes toward specific issues that might be gathered through public-opinion surveys (B\&N 2014, Elazar 1970 and Roskin 2014).

Political culture is potentially a powerful, unifying concept of political science. When it was first proposed by Gabriel Almond (1956) and subsequently employed in "The Civic Culture" (Almond and Verba 1963), the term promised to solve in a scientific, cross-cultural valid way the micro-macro problem: the classic problem of specifying how people affect their political system, and vice-versa. The success of anthropologists in studying culture assured political scientists that, properly defined, political culture could be studied in all societies. Although formalizing and operationalizing the concept might require new methods, new data, and new theories, the concept itself seemed unproblematic (Chilton 1988, Wilson 2000, and Elazar 1972). Political culture today deals with citizens behaviors in relations to political development and governance in human society. It is one of the most intellectually stimulating issues to study in the area of comparative politics. In some other instances, political culture can be conceptualized as the psychological study of the actions of citizens in relations to government and state policies. Political culture thus behaviors affects state democratic development and processes to a larger extent. In West Africa and Nigeria in particular, both elite and mass political cultures and the behaviors of both the ruling elites and governed masses put together play a serious role in determining the democratic development of a country. Every country as US government (2014) and Durverger (2006) observe d has a political culture-widely shared beliefs, values, and norms that define the relationship between citizens and government, and citizens to another.

Beliefs about economic life as Haggard and Kaufman (1995) narrates are part of the political culture of a state. This is however because politics as Huntington (1991) want us to believe affects economics. A good understanding of a country`s political culture as Appadurai (1973) and Laski (1986) explains help in assisting one to understand how a country`s government is designed as well as the political decisions its leaders make. Any country's political culture reflects the impact of its history on the way people think about politics and their society as a whole. In Nigeria's case, the lack of unity and support for the regime and, at times, for the very existence of Nigeria have plagued it since the country gained its independence. What's more, the actions of the elites since 1960 have undoubtedly left the country more alienated and polarized than it was forty years ago. That alienation and polarization, in turn, are reflected in what average people do politically, thus adding yet another strain to an already over loaded system (Polazzo 2014). The political decisions leaders make are messages of what the political attitudes of citizens are in relations to politics and government in a particular country.

\section{Democratic Transition}

Democratic transition is the movement from one government to another. Such transition and movement is created by tenure expiration in some cases. But in other, change of government using various methods is also a transitional development. A popularly accepted notion is the view that democratic transition implies the movement from one democratic government to another. Democratic transition is a switch from one government to another. But then, Omoruyi (2003) posits that it is not a one day switch. It is a switch that takes time. In Oyediran (1981), Joseph (1992) and Elaigwu's (1986) narrations, democratic transition is a designed program of movement from totalitarian regime to a democratic order. Under apartheid South Africa, Mandela (1994) conceived democratic transition as a gradual movement from minority to majority rule. Omoruyi (2003) further submits that democratic transition is a broad threshold that commences with the empowerment of individual citizens and group that eventually leads to the installation a winner of an election and his survival in office of whole rule. This implies that democratic transition is a systematic approach to the establishment of a democratic regime in the context of totalitarian regime states. It is an act of trying to achieve and make democracy work. And making democracy work as NDI (2014) submits require informed and active citizens who understand how to voice their interests, act collectively and hold public officials accountable.

Democratic transition is a process of movement leading towards the establishment of civil rule therefore, Przeworski et al (2000) considers it as democratization. And democratization as Inglehart and Welzel (1993) is a movement to a more democratic political regime. Putman et al (1993) asserts that it may be the transition from an authoritative regime to a full democracy. Democratization as Colomer (2000) believes is a transition from an authoritative political system to a semi-democracy. But Epstein et al (2004) submits that it is a transition from a semi-authoritarian regime to a democratic political system. Acemoglu and Robinson (2002) subscribed to the view that democratization is a transition from less to a more democratic political system. They also posit that economic development, history and civil society are some of the factors that influence democratization. Nigeria`s economic development experience and political history as well as the nature of its civil society shape its democratization process at different times that the country adopted such attempts to lead the nation into democratic rule.

Democratic transition has been considered as 
democratization since it entails a gradual process and switch from one government to another. Democracy is thus an essential issue in democratic transition and democracy as Coleman and Lawson-Reiner (2013) observed is struggling. Epstein et al (2004) contends that the study of democratization is one of the most vulnerable literatures in comparative politics. It is one of the most vigorous, as controversies over theory and method interact with empirical research in debating the origins and determinants of democratic forms of government. In Nigeria, the democratic form of government became necessary on realization of the political and economic backwardness that was setting into the system and polity as a result of the age-long military regime that refused to transfer political power to a democratic government aspired by the Nigerian people. The period between political independence and final transition to civil rule in the country in 1999 witnessed an unprecedented military rule accompanied by constitutional suspension and disrespect for the fundamental human rights of citizens and the rule of law. But still under civil rule, periodic occasional insecurity situations arising at different locations in the country left most of the ordinary citizens aspiring for a military regime which they just came out from few years ago. Both mass and elite political culture affects democratic transition in the country. And the level of influence which attitudes have on the development of democracy in the country thus, affect also the economic and political development of the nation.

\section{The Nigerian Experience}

In the political history of Nigeria, transition and repeated democratic processes are greater part of outstanding records. Several military regimes have been established in the country than civilian ones. The records of coups and counter coups are also high. Instituted programs of transferring political power to elected democratic government are numerous and in some cases such transitions were interrupted by soldiers themselves that instituted them. Since the attainment of political independence in 1960, Nigeria as a nation has witnessed a number of transition programs. Some of these programs ended well with transfer of political power to civilian democratically elected president. But in some cases, the civil regimes are again toppled shortly or later after establishment. The attitudes of the elites and sometimes of the masses are political culture that has affected democratic transition and transition to civil rule programs in the country. They are the same causes of the elections and post-election violence been witnessed in the country's political system whenever democratic transition is due. O'Donnell et al (1986) contends that transition is the interval between one political regime and another. Transition to Diamond et al (2014) is delimited on one side, by the launching of the process of dissolution of an authoritarian regime and, on the other, by the installation of some form of democracy. O'Donnell et al (1986) further believes that it is the return to some form of authoritarian rule, or the emergence of a revolutionary alternative. This is because transition to him is a process leading to the establishment of a political system but it not the system itself.

Since independence in 1960, Lewis (1994) reports that Nigeria has experienced 24 years of military rule. Following the downfall of the First Republic in 1966, authoritarian government has been interrupted only by a brief civilian interregnum during the second republic (1979-1983). Yet democratic aspirations as Oyediran (1981) submits have persisted in Nigeria. This democratic agenda to Lewis (1994) has been verbally reaffirmed by civilian and the military leaders alike, even if the substance of democracy is lacking. The authoritarian regimes that rule Nigeria from the termination of civil rule in 1966 to its reestablishment later in 1979 were characterized by elites who do not in any away nurture the ambition to relinquished political power as soon as they become head of state. With the exception on of the transition that brought in a democratic regime in 1979, all change of government witness between 1966 to 1979 were hatched by either coup or counter coup by the military. And these military regimes all had different transition to civil rule program often altered by their successive regime. Political culture of the masses as Nwokedi (1994) pointed out also assist in the disruption of democratic transition in Nigeria. The massive post-election demonstrations that accompanied the 1966 national elections believed to have been rigged in favor of the ruling Northern People's Congress (NPC) resulted in political tension and conflicts across the western region of the country thus creating the opportunity for military to intervene in politics. The zero sum tactic of leadership employed by the military that overthrew the NPC led civilian government and aggrieved fear of marginalization that came up resulted in a massive request that culminated in a counter coup in the same 1966. The military designed several transition to civil rule programs and abolish them at later stages closer to their end. Designing transition programs and reneging in completing implementation couple with the political tensions that these generated from the part of the masses are additional reasons for the counter coup that ushered in another military regime in 1976. This development led to the drafting of another transition to civil rule program which ended in 1979.

In 1984, out cried complains of the Nigerian people and their attitudes of open criticisms discredited not only the civilian government after the departure of soldiers from power in 1979. Massive condemnation of the regime as a result of conflicts which were springing up across the country as well as pronounced corruption and indiscipline on the parts of political elites dragged Nigeria back into an authoritarian regime towards the end of 1984-an administrative condition the country remained in until later in 1999. Between these periods, several coups and counter coups were recorded. Some were successive while others were abortive and failed ones. Transition to civil rule programs during these periods were also several in number but none succeeded in ushering in a democratic government 
if the not urgent one designed after the death of General Sani Abacha. In Nigerian government and politics especially in relations to democratic transition, soldiers have proven that they can be more competent than the politicians in administrative politics and maneuverers. Their logic of designing transition program and backing it up with contradictory elements that are capable of affecting complete implementation demonstrate how logical they are in tenure extension while in power. The administrative dribbling tactics of General Babangida's administration and the confusing political culture its created in Nigerian masses are still part of the political records of Nigeria.

Oyediran and Agbaje (1991) posits that after coming to power in 1985 via what might be described as a "palace coup", General Babangida quickly earned himself the sobriquet of "Maradona" of Nigerian politics. In October 1989, the president surpassed his own record of unpredictability and unorthodoxy, and surprised even the closest watchers of his regime by announcing that two parties would be established by fiat and provided with initial funding in the context of the agreed program of transition to democratic civil rule, laid out between 1986 and 1987, and scheduled to terminate with the inauguration of the Third Republic in 1992. Prior to the end of the transition program, it became clearer that General Babangida was not in any way willing to leave or complete the transition program leading to the transfer of political power to a democratically elected president. Repeated presidential primaries were cancelled at different times. Although the political system was a sort of diarchy having civilian governors and parliamentarians in the both federal houses of assembly while the President and his Armed Forces Ruling Council (AFRC) were all military officers and could over rule decisions taking by the National Assembly. Successful presidential primaries were allowed leading to a national election conducted using open ballot system. Election results half way announced were annulled and the annulment of the June 12 presidential election triggered political tensions and conflicts mainly in the south-western region of Nigeria. This development forced the military out of power unceremoniously in July 1993 resulting in the emergence of an Interim National Government (ING). The ING lacks legitimacy among the Nigerian people. Its constitutionality remains questionable in relations to establishment and operation. Tensions which started after presidential election cancellation grew instead of coming to end. Socio-economic and political tensions set in and elites conspired to bring in the military again putting an end to the shortly instituted ING.

An undefined democratic transition program adopted by the General Sani Abacha led military junta was discovered to have no specific direction. The transition was expected to clearly define when authoritarian regime will end and civil one starts-a definition that was not specifically stated in the transition program. Multi-party politics which was accepted to replace the initial two party system adopted in the aborted third republic resulted in the emergence of five political parties all willing to adopt unanimously without primaries the ruling General Abacha as their presidential candidate. These development further triggered political tensions across the country. Alleged state sponsor detonation of explosives in public places grew and the apprehension of political elites conceived as opposition elements rose on daily basis. These couple with the pariah status of the nation as a result of suspension from international system and community metamorphosed in internal economic hardship that discredited the regime before its own people. Several politicians and elites fled on exile to escaped been murdered by the regime which they were opposing. Phantom coups, Kangaroo trials and eliminations set into the system. Inequalities grew higher than before although economic stability amidst serious poverty was recorded. Urban security was maintained across the country but rural conflicts and highway armed robbery also grew due to poverty and joblessness. These developments persisted until the regime was ended with the unexpected death of the military head of state in June 1997. The Provisional Ruling Council (PRC) announced a successor who came up with a transition program that successfully resulted in military disengagement from government and politics in May 1999. This transition program and the one that led to the transfer of power to civilian democratically elected president in 1979 are recorded in Nigeria history as the only successful democratic transitions the country has had since independence in 1960.

Elections under the fourth republic that is from 1999 till date were characterized by ineffective administration at all stages and levels (before, during and after), resulting in damagingly discredited outcomes. This was due in large part to the weak institutionalization of the primary agencies of electoral administration, particularly the Independent National Electoral Commission (INEC) and the political parties (Omotola 2010). The weak institutionalization of INEC especially in relations to inability to conduct free, fair and credible elections influences the mass political culture and behaviors of the Nigerian people in the fourth republic. Since 1999 till date, the ruling PDP has continue to lead comfortably in presidential, gubernatorial and parliamentary elections conducted in Nigeria. Several forms of alliances and merger by the other political parties have not been able to deprive PDP of these comfortable leads. Elections results have triggered post-election conflicts resulting in the death of innocent citizens across the nations at different times. Elites especially politicians are under greater suspiciousness of promoting conflicts to make the country ungovernable and politically unstable for the ruling PDP on ground of political party differences. The birth of political thugs ever willing to kill or die in defense of party interest and in safeguarding the interest of political Godfathers is high. And today the political culture or attitudes of the average Nigerian citizen is retrogressive and brutal in relations to national interest. This unpatriotic attitude affects democratic transition in the country. The caliber of conflicts witnessed during and after elections in the country are examples of this view.

\section{Conclusions}


Nigerians share a lack of faith in their government, the rule of law, a sense of being oppressed, and of not receiving their fair share of Nigeria's bounty (Agbu 2004). Contrary to the widespread expectation that the inauguration of the civilian administration would usher in democratic stability, the nature of politics of transition program and the reluctance of the post-military regime to address the national question have led to the resurgence of social groups that make demands for incorporation and empowerment. The central argument is that unbridled competition of power, and the failure of government to deliver democratic dividends, have resulted in violent conflicts, especially between ethnic and religious groups, endangering the country's nascent democracy (Ukiwo 2003). The failing statues of the Nigerian state on daily basis are not only translating in the development of conflict conditions and situations that are threatening the stability of the state and the legitimacy of government. State inability to deliver good governance through the development of social services which will result in improve condition of living is also affecting the attitudes and thinking of the citizens-a development that also determines their attitudes and reactions to government policies and state leadership. Good governance, especially transparency and equity as Ukiwo (2013) further submits would restore governmental legitimacy, inter-ethnic and religious harmony and promote democratic consolidation. And these in the long run will affect behaviors and thus reshape the political culture of the Nigerian people towards effective democratic transition and development.

\section{REFERENCES}

[1] Acemoglu, D. and Robinson, J. (2002): The Political Determinants of Dictatorship and Democracy. Massachusetts: Massachusetts Institute of Technology (MIT).

[2] Agbu, O. (2004): Ethnic Militias and the Threat to Democracy in Post-transition Nigeria. Goteborg, Sweden: Elanders Infologistics vast $\mathrm{AB}$.

[3] Almond, G. A. and Verba, S. (1965): The Civic Culture. MA: Little Brown and Company.

[4] Almond, G. A. et al (2006): Comparative Politics Today. World Edition. New Delhi: Linder sky (PVT) Ltd.

[5] Appadurai, A. A. (1973): The Substance of Politics. New Delhi: Oxford University Printing Press.

[6] B \& N (2014): Political Culture and Public Opinion. New York: Spark notes LLC.

[7] Chilton, S. (1988): "DEFINING POLITICAL CULTURE". In the Western Political Quarterly Vol 41, No. 3, September 1988, pp. 419-445.

[8] Coleman, I. and Lawson-Renner, T. (2013): “A User`s Guide to Democratic Transitions: A how- to guide for reformers around the World". IN DEMOCRACY LAB: TRACKING A WORLD OF CHANGE. A Special Project with the Lagatum
Institute.

[9] Colomer, J. M. (2000): Strategic Transitions. Baltimore, Md: The Johns Hopkins University Printing Press.

[10] Diamond, L. J. (Ed) (1984): Political Culture in Developing Countries. London: Heinemann.

[11] Diamond, L. J., Linz, J., and Lipset, S. M. (Eds) (2014): Politics in Developing Countries. $2^{\text {nd }}$ Edition. New York: Kumarian Press. LYNNER RIENNER.

[12] Durverger, M. (2006): Introduction to the Study of Politics. Revise Edition. London: Heinemann.

[13] Elazar, D. J. (1972): American Federalism: A View from the States. New York: Thomas Y. Crowell.

[14] Elazar, D. J. (1970): Cities of the Prairie: the metropolitan frontier and American Politics. New York: Basic.

[15] Elaigwu, J. I. (1986): Gowon. Ibadan, Nigeria: University Printing Press.

[16] Epstein, D. L. et al (2004): Democratic Transition. Working Paper No. 101. Harvard: Harvard University Printing Press.

[17] Gibson, J. L. (2001): "Social Networks, Civil Society, and the Prospects for consolidating Russia`s democratic transition". In America Journal of Political Science, vol 45, no.1, January 2001, pp.51-68.

[18] Haggard, S. and Kaufman, R. (1995): The Political Economy of Democratic Transitions. Princeton: Princeton University Printing Press.

[19] Huntington, S. P. (19991): The Third Wave. Norman, OK: Oklahoma University Printing Press.

[20] Ingle hart, R and Welzel, C. (2005): Modernization, Cultural Change and Democracy: The Human Development Sequence. New York: Cambridge University Printing Press (CUP).

[21] Joseph, R. (1992): “Africa: The Rebirth of Freedom”. In Journal of Democracy, vol 18, no. 6, pp.11-25.

[22] Kertzer, D. I. (1988): Ritual, Politics, and Power. New Haven CT: Yale University Printing Press.

[23] Laski, H. J. (1986): A Grammar of Politics. New York: Allen and Unwin.

[24] Lewis, P. M. (1994): "END GAME IN NIGERIA? THE POLITICS OF A FAILED DEMOCRATIC TRANSITION". In Journal of African Affairs vol 93, no.372, July 1994, pp.323-340.

[25] Mandela, N. (1994): Long Walk to Freedom. Boston: Little Brown.

[26] NDI (2014): ABOUT NDI. Massachusetts, Washington DC: The National Democratic Institute (NDI).

[27] Nwokedi, E. (1994): "Nigeria's democratic transition: Explaining the annulled 1993 Presidential election". In The Round Table: The Commonwealth Journal of International Affairs vol 83, issue 330, pp.189-194.

[28] O`Donnell, G. Schumitter, P. and Whitehead, L. (Eds) (1986): Transitions from Authoritarian Rule: Prospect for Democracy. Baltimore: The Johns Hopkins University Printing Press.

[29] Omoruyi, O. (2003): "DEMOCRATIC TRANSITIONS IN AFRICA: The Case of Nigeria". In africandemocracy@hotm 
ail.com.

[30] Omotola, J. S. (2010): "Elections and Democratic Transition in Nigeria under the Fourth Republic". In OXFORD JOURNALS of African Affairs, 17, September 2010.

[31] Oyediran, O. (1984): Survey of Nigerian Affairs 1976-77. Lagos: Macmillan.

[32] Oyediran, O. and Agbaje, A. (1991): "Two-Partyism and Democratic Transition in Nigeria". In Journal of Modern African Studies, vol 29. Issue 02, June 1991, pp. 213-235.

[33] Polazzo (2014): "Political Culture and Participation in Nigeria”. In www.polazzo.com/nigeria_4.htm.

[34] Przeworski, A. et al (2000): Democracy and Development: Political Institutions and Well-Being in the World, 1950-1990. Cambridge: Cambridge University Press (CUP).
[35] Putman, R. D. et al (1993): Making Democracy Work: Civic Traditions in Modern Italy. Princeton: Princeton University Printing Press.

[36] Roskin, M. G. (2014): "Political Science and Political Culture". In ENCYCLOPAEDIA BRITANICA. London: Oxford University Printing Press.

[37] Schaffer, F. C. (1998): Democracy in Transition: Understanding Politics in an Unfamiliar Culture. Ithaca, New York: Cornell University Printing Press.

[38] Ukiwo, U. (2003): "Politics, ethno-religious conflicts and democratic consolidation in Nigeria". In The Journal of Modern Africa Studies, vol 41/ issue 01/ March 2003, pp.115-138.

[39] Wilson, R. W. (2000): "The Many Voices of Political Culture: Assessing Different Approaches". In World Politics 52 (January 2000), 246-73. 